\title{
The Psychological Well-Being, Happiness and Life Satisfaction of Music Students
}

\author{
Erol Demirbatir ${ }^{1}$, Ayhan Helvaci ${ }^{1}$, Nilufer Yilmaz ${ }^{1}$, \\ Gulnihal Gul ${ }^{1}$, Ajda Senol ${ }^{1}$, Nazan Bilgel ${ }^{2}$ \\ ${ }^{1}$ Department of Music Education, Faculty of Education, Uludag University, Bursa, Turkey \\ ${ }^{2}$ Department of Family Medicine, Faculty of Medicine, Uludag University, Bursa, Turkey \\ Email: nazan@uludag.edu.tr
}

Received August 28 $8^{\text {th }}, 2013$; revised September 26 ${ }^{\text {th }}, 2013$; accetped October $25^{\text {th }}, 2013$

Copyright (C) 2013 Erol Demirbatir et al. This is an open access article distributed under the Creative Commons Attribution License, which permits unrestricted use, distribution, and reproduction in any medium, provided the original work is properly cited.

\begin{abstract}
Studies showed that university and college students are vulnerable to mental health problems. High rates of depression, anxiety and stress among students have generated increasing public concern in western societies, but in eastern societies this issue remains mostly undiscovered. The healing force of music has been known since ancient times and studies showed the positive impact of music on mental health problems. However, few studies have been conducted on music students' psychological well-being. In this study we wanted to assess the psychological well-being of undergraduate music education students in terms of depression, anxiety and stress as well as their happiness and life satisfaction levels. A second objective of this study was to examine the effects of different types of classical music (baroque versus romantic/post-romantic) on depression, anxiety and stress levels as well as on perceived happiness and life satisfaction. A total of 69 students participated in this study, with 35 assigned to Group I (listened to baroque music) and the other 34 assigned to Group II (listened to romantic/post-romantic classical music). No statistically significant relationships were found between depression, anxiety and stress levels and any of the socio-demographic characteristics that were studied. This was the same for happiness and life satisfaction levels. There was, however, a significant relationship between economic status and life satisfaction which was found to be positively related. A significant negative correlation was determined between depression and happiness and between depression and life satisfaction. The difference between depression, anxiety and stress levels as well as happiness and life satisfaction levels for Group I and Group II students was not statistically significant.
\end{abstract}

Keywords: Depression; Anxiety; Stress; Happiness; Life Satisfaction; Students

\section{Introduction}

Evidence that suggests that university and college students are vulnerable to mental health problems has generated increasing public concern in western societies (Stanley \& Manthorpe, 2001). High rates of depression, anxiety and stress among students all over the world in higher education have been revealed in many previous studies (Adewuya, Ola, Olutayo, Mapayi, \& Oginni, 2006; Nerdrum, Rustøen, \& Rønnestad, 2006; Ovuga, Boardman, \& Wasserman, 2006; Stewart-Brown, Evans, Patterson, Doll, Balding, \& Regis, 2000; Wong, Cheung, Chan, Ma, \& Tang, 2006; Voelker, 2003). Psychological morbidity among undergraduate students represents a neglected problem and holds major implications for campus health services and mental health policy-making (Stewart-Brown et al., 2000; Poch, Villar, Caparros, Juan, Cornella, \& Perez, 2004; Royal College of Psychiatrists, 2007). Undergraduate students need to cope with psychological and psychosocial changes that are connected to the development of an autonomous personal life and additionally they have to cope with the academic and social demands that they encounter in university studies and in their preparation for professional careers. Therefore, the period of undergraduate education is regarded by many as important for the development of systems and intervention methods that may prevent or reduce mental health problems (Gjerde, 1993).

The healing force of music has been known since ancient times. There are many studies about the positive impact of music therapy in psychiatric disorders and in many other health problems (Evans, 2002; Erkkila, Punkanen, Fachner, AlaRuona, Pöntiö, Tervaniemi, Vanhala, \& Gold, 2011; Rao, Nainis, Williams, Lanfner, Eisin, \& Paice, 2009; Smolen, Topp, \& Singer, 2002; Wang, Wang, \& Zang, 2011). Therefore, it can be suggested that music students may have low levels of depression, anxiety and stress compared to other undergraduates. However few studies have been conducted on music students in terms of psychological well-being. Spahn, Strukely, and Lehmann (2004) found depression and anxiety rates among music students to be higher than those of other undergraduates. Some studies have assessed burnout and stress of undergraduate music students and found high levels of burnout and stress (Bernhard, 2005; 2010; Orzel, 2010; Sternbach, 2008).

In Turkey, epidemiological data about psychological morbidity among undergraduate students have not been researched in depth, although some recent studies have revealed high rates of depression, anxiety and stress and even suicidal tendencies 
among university students (Aktekin, Karaman, Senol, Erdem, Erengin \& Akaydin, 2001; Arslan, Ayranci, Unsal, \& Arslantas, 2009; Bayram \& Bilgel, 2008; Bostanci, Ozdel, Oguzhanoglu, Ozdel, Ergin, Ergin, Atesci, \& Karadag, 2005; Ozdemir \& Rezaki, 2007). In their study of music students, Karaoglu \& Karaoglu (2009) found high rates of depression and anxiety but no differences compared to other undergraduate students.

Another study found the mean depression, anxiety and stress scores to be significantly higher among music education students compared to medicine students (Demirbatir, Bayram, \& Bilgel, 2012).

The purposes of this study are:

1) To assess the depression, anxiety and stress levels as well as the levels of happiness and life satisfaction among music education students;

2) To examine the effects of different types of classical music on the psychological well-being of the music education students;

3) To evaluate the possible effects of socio, economic and demographic differences on mood, perceived happiness and life satisfaction;

4) There are many studies in the literature about psychological well-being of students in general and about music students in particular. Although most of these studies were performed in western countries. The novelty of this study is it concerns data from an eastern culture and addresses the impact of different types of classical music (from baroque and from romantic/post romantic era) on psychological well-being.

\section{Materials and Methods}

This study was a randomized, controlled, repeated measures study conducted in one university in Turkey and was based on self reporting. Figure 1 shows the summary of the workflow.

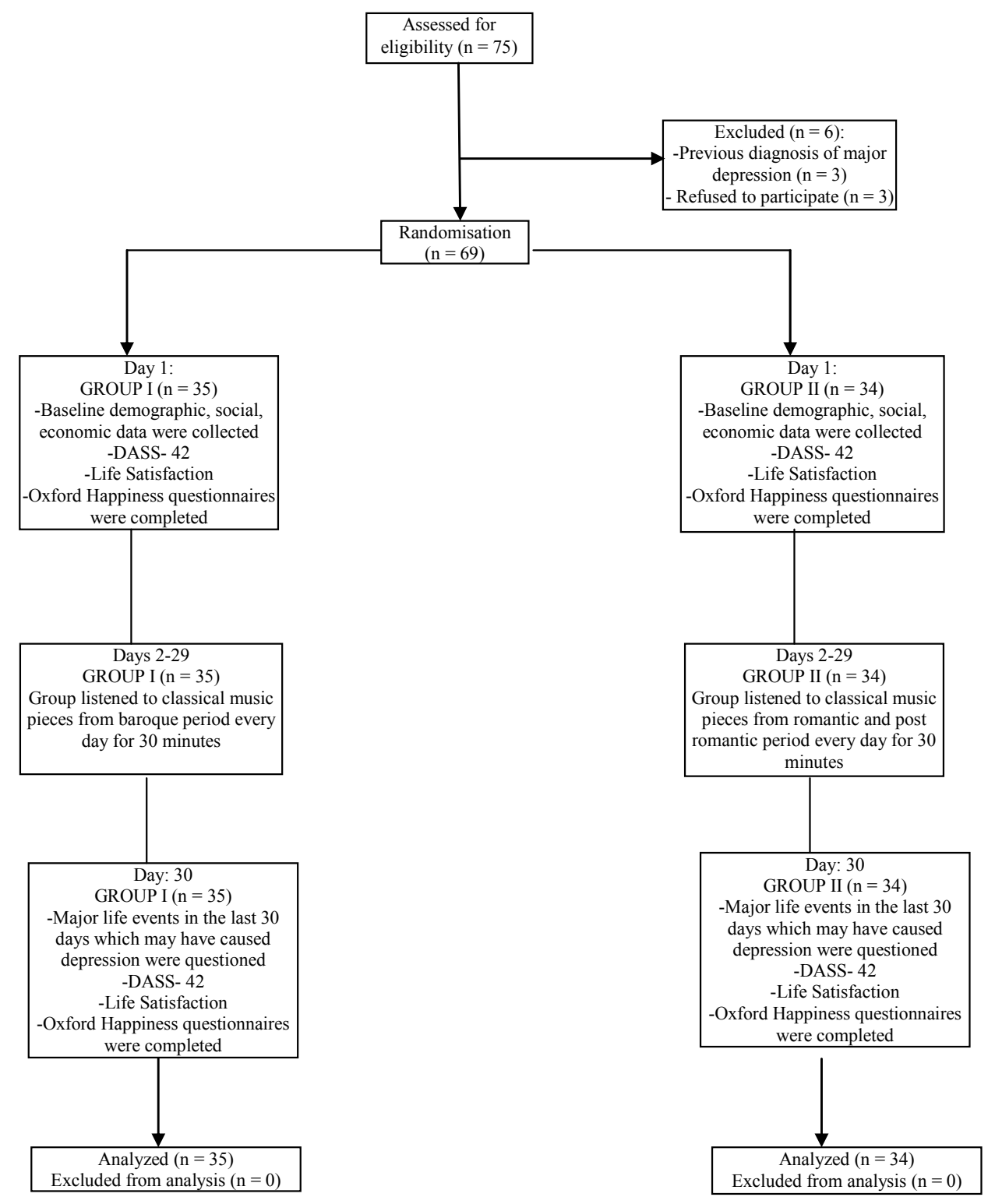

Figure 1.

Summary of the workflow. 


\section{Participants}

First and second year music education students of the corresponding university were the suggested study group. Inclusion criteria were voluntary participation and not being diagnosed with any psychological disorder. From a total of 75 students 3 refused to participate and 3 were diagnosed with major depression and were under therapy and therefore were excluded. The remaining 69 students were assigned randomly to either Group I or Group II each participant was given a number from 1 - 69, and 35 unique numbers were selected from the random digits table ranging from 1 - 69. Participants matched with the generated number were allocated to Group I and those not matched were allocated to Group II. After the allocation and during the study none of the participants refused to continue, so the study was completed with a zero drop-out rate.

\section{Instruments}

We used 4 different questionnaires for collecting the data. All of them depended on self reporting.

1) Socio-demographic-economic data were collected by a questionnaire prepared by the authors. Questions were asked regarding age, gender, economic status (poor, moderate, good), place of residence (together with family, in a house together with friends, in a dormitory etc.), educational status of father and mother (primary, secondary, high, higher education), place of residence before university education (village, town, big city), number of sisters and/or brothers, marital status of parents (married, divorced, separated), satisfaction regarding their current education (yes/no).

2) DASS-42: Depression, anxiety and stress were measured using the 42-item Depression Anxiety and Stress Scale (DASS) developed by Lovibond \& Lovibond (1995a; 1995b) and was constructed for the Turkish language by Uncu, Bayram, \& Bilgel (2007). This instrument measures current symptoms of depression, anxiety, and stress. Each of the three scales consists of 14 items answered using a $0-3$ scale, where $0=\operatorname{did}$ not apply to me at all, and $3=$ applied to me very much or most of the time (range of possible scores for each scale is $0-42$ ). Scores considered in the normal range are 0 - 9 for depression, $0-7$ for anxiety, and $0-14$ for stress. Scores above these ranges indicate the degree of the problem from mild to extreme. The DASS-42 is a self-administered instrument with well-established psychometric properties in clinical and non-clinical samples, and has been shown to differentiate between the three states of depression, anxiety and stress (Lovibond \& Lovibond, 1995a; 1995b; Antony, Bieling, Cox, Enns, \& Swinson, 1998; Crawford \& Henry, 2003). The depression scale assesses dysphoria, hopelessness, devaluation of life, self deprecation, lack of interest or involvement, anhedonia and inertia. The anxiety scale assesses autonomic arousal, skeletal muscle effects, situational anxiety and subjective experience on anxious effects. The stress scale is sensitive to levels of chronic non-specific arousal. The scale assesses difficulty relaxing, nervous arousal and being easily upset or agitated, irritability or over-reaction and impatience. The Turkish version of the DASS-42 has good reliability and validity (Bayram \& Bilgel, 2008; Bilgel \& Bayram, 2010).

3) The Oxford Happiness Questionnaire: Developed by Hills $\&$ Argyle (2002) and was constructed for the Turkish language by Seker \& Gencdogan (2006). The Turkish version showed good reliability and validity (Dogan \& Cotok, 2011). This scale consists of 29 items answered using a $1-6$ scale, where $1=$ did not apply to me at all, and $6=$ applied to me very much or most of the time (range of possible scores is 29 - 174). Higher scores indicate higher levels of happiness.

4) The Satisfaction with Life Scale: Developed by Diener, Enmors, Larger (1985) and was constructed and validated for the Turkish language by Koker (1991). This scale consists of 5 items answered using a $1-7$ scale, where $1=\operatorname{did}$ not apply to me at all, and $7=$ applied to me very much or most of the time (range of possible scores is 5 - 35). Higher scores indicate higher levels of life satisfaction.

\section{Types of Music}

A total of 28 classical music pieces from the Baroque and romantic/post romantic periods were selected by the music education teachers who participated in this study. They were as follows:

For Group I (Music from the Baroque period):

1) Johann Sebastian Bach: Brandenburg Concerto No. 3 in G Major, BWV 1048:

Three movements: a) no tempo indication, b) Adagio, c) Allegro. A charming and simply piece in Vivaldi's concerto style. Vibrant and fast paced work. Approximately 20:51 minutes.

2) Johann Sebastian Bach: Missa BWV 232 in B Minor. Trinitarian movement with largely symmetrical structure and Domine Deus in the middle:

a) Gloria in Excelsis, five part chorus (soprano I, II, Alto, Tenor, Bass) in D Major, marked vivace $3 / 8$ time. Approximately 5:52 minutes

b) Cum Sancto Spiritum five part chorus (soprano I, II, Alto, Tenor, Bass) in D Major, marked vivace 3/4 time. Approximately 4:02 minutes.

3) Johann Sebastian Bach: Cantata no. 147: Begins with an elaborate chorus in C Major. The celebratory tone is established by the fanfare like opening section for the orchestra. The vocal parts are in fugal form with the entries staggered from the upper register to the lowest succession and later this ordering is reversed when the bass voices are heard first of all in reprise. Approximately 30:29 minutes.

4) Georg Friedrich Handel: Water Music Suite No. 1 in $F$ Major, HWV 348. The Overture that begins the first Water Music Suite is in two large sections. The stately and eminently restrained exuberance of the first and slower section, built entirely out of a single ornamented pick-up gesture, finally boils over into the vivacious, partially fugato, allegro portion of the piece. Approximately 29:59 minutes.

5) Georg Friedrich Handel: Music for the Royal Fireworks in D Major, HWV 351. Has five movements. a) Overture. AdagioAllegro-Lentement b) Bourrée c) La paix. Largo alla Siciliana d) La réjouissance. Allegro e) Minuet $1 \& 2$. The suite begins with a suitably pompous and ceremonial Overture in the French style: a slow, dotted-rhythm introduction followed by a contrapuntal Allegro. The suite continues with a lively Bourée, a quieter movement entitled "La paix", the ebullient "La réjouissance", and a final Minuet. A second Minuet, in D minor, which seems to have been added later, was probably used by the composer as a trio section before a final triumphant return to the main Minuet in D major. Approximately 19:17 minutes.

6) Antonio Vivaldi: Concerto No I in E Major, op. 8 no. 1 RV 269. Allegro-Largo e pianissimo sempre danza pastorale. 
Approximately 10:38 minutes.

7) Antonio Vivaldi: Concerto No II in G Minor, op. 8 no. 2 RV 315. Allegro non molto, adagio presto, tempo impetuoso d'estate. Approximately 10:00 minutes.

8) Antonio Vivaldi: Concerto No III in F Major, op. 8 no. 3 RV 257. Allegro-Adagio-Allegro (La Caccia). Approximately 11:09 minutes.

9) Antonio Vivaldi: Concerto No IV in F Minor, op. 8 no. 4 RV 297. Allegro non molto-Largo-Allegro. Approximately 08: 30 minutes.

10) Antonio Vivaldi: Flute Concerto in D Major. RV 428

11) Antonio Vivaldi: Concerto for strings and violoncello "Alla Breve"

12) Georg Philip Telemann. Suite in E Minor for 2 flutes, strings and basso continuo, TWV55 Overture. Approximately 08:55 minutes. Rejouissance. Approximately 04:15 minutes.

13) Georg Philip Telemann. Concerto in A Major for flute, violin, cello and strings Allegro. Approximately 06:06 minutes

14). Domenico Scarlatti: Sonata for the Harpsichord in A Major K208. Broad melodic movement, regular rhythm, soft and sonorous resonance. Approximately 04:01 minutes.

For Group II (Music from the Romantic and Post-Romantic period)

1) Igor Stravinsky: Inferno Dance from Firebird Ballet. Stravinsky created non-diatonic melodies based on dissonant intervals such as the tritone. The magical sound of glissando harmonics, explosive dynamics and ferocious rhythmic syncopations and malevolent non-diatonic intervals in the melodic line. The scale contains alternating tones and semi-tones and that can be broken down into two diminished 7ths. Stravinsky's music could be described with words such as staccato, detached, pointed, fierce, deliberate and exaggerated. Approximately 8:30 minutes.

2) Igor Stravinsky: Symphony in C. Is a retreat into the "pure music" styles of Bach, Beethoven, and Haydn and a work of the Stravinsky's neo-classical period. Regarding its style, Stravinsky acknowledged a division of the symphony into halves. The first two movements, composed in Europe, use more traditional rhythmic patterns and harmonization. The last two movements use frequent modulations of rhythm and are much more chromatic.

a) Moderato alla breve. Approximately 9:00 minutes.

b) Larghetto (concertante). Approximately 6:00 minutes.

3) Igor Stravinsky: Les Noches, (The Wedding) is a dance cantata, or ballet with vocalists and one of Stravinsky's most relentlessly intense and slamming' pieces. Scoring: soprano, mezzo-soprano, tenor, and bass soloists, mixed chorus, and two groups of percussion instruments-pitched percussion, including four pianos, and unpitched percussion. Approximately 22:00 minutes.

4) Dmitri Shostakovich: The Symphony No. 5 in D minor, Op. 47. Deep, meaningful, gripping music. Effectively he had mastered the essence of the Romantic symphony giving the audience an outlet for their sorrow. During the first performance of the symphony, people were reported to have wept during the Largo movement. The music has an atmosphere of mourning, contained echoes of the panikhida, the Russian Orthodox requiem. The use of the tremolo in the strings is an expression of immeasurable grief. The symphony is approximately 45 minutes in length and has four movements: Moderato, allegretto, largo and allegro non troppo.

5) Dmitri Shostakovich: The Golden Age Op. 22, is a ballet in 3 acts, 6 scenes. Shostakovich extracted a suite from the ballet, Op. 22a. It has four movements: Introduction (Allegro non troppo)-Adagio-Polka (Allegretto)-Dance.

6) Dmitri Shostakovich: Symphony No. 2 in B major, Op. 14 "To October", was composed for the 10th anniversary of the October Revolution as gestural, geometric music without emotional structure, with the intent of reflecting speech patterns and physical movements in a neo-realistic style. It has one movement with four sections, the last of which includes a chorus praising Lenin and the revolution. Approximately 20:00 minutes.

7) Dmitri Shostakovich: Quarter Note $=152$. A meditative episode which Shostakovich described as the death of a child killed on the Nevsky Prospect.

8) Modest Mussorgsky: A Night on the Bare Mountain. A symphonic poem, dreadfully haunting, a dark piece of music opens with an allegro feroce, with a turbulent figure in the strings against which the trombones, tuba, and bassoons thunder the theme. The dance is saturated with Russian folk idiom and appears in strongly marked rhythms in the oboes and clarinets, presenting an effective contrast to the opening theme. The allegro feroce of the opening returns, the brass weaving its theme against rapid chromatic passages in woodwinds and strings. A new dance theme appears, at first in fairly slow tempo, but gradually working up to a frenzied climax. The bell tolls mournfully six times. Strings and harp announce the coming of dawn. Approximately 10:14 minutes.

9) Modest Mussorgsky: The Seamstress scherzino for piano. Approximately 2:42 minutes.

10) Modest Mussorgsky: Intermezzo in modo classico. Mussorgsky's best and most characteristic piece for the piano. The work was composed in the winter of 1861, while Mussorgsky was still living in the country after a nervous breakdown. Mussorgsky orchestrated the work in 1867, giving it the title intermezzo symphonique in modo classico. Approximately 7:10 minutes.

11) Sergei Rachmaninoff: Piano Concerto No: 2 in C Minor Op. 18. A concerto for piano with three movements. Moderato (C Minor)-Adagio sostenuto-Pui animato (C Minor-E Major)-Allegro scherzando (E Major-C Minor-C Major). The Second Piano Concerto is a beautiful piece of music, full of romantic passion and sublime melody. Rachmaninoff composed this concerto after a nervous breakdown caused by the disastrous premiere of his First Symphony. He was nursed back to health by psychiatrist Nikolai Dahl, and dedicated the second Concerto to Dr. Dahl. The concerto contains poetic melancholy melodies, rich orchestration, well-balanced between piano and orchestra. The first movement is in sonata-allegro form. The opening movement begins with a series of bell-like tolling on the piano that builds tension which lead to the portentous initial theme, swept through powerfully by the orchestra. In this first section, the orchestra carries the Russian-character melody while the piano makes an accompaniment made of rapid oscillating arpeggios. The second theme is lyric. Motives from both themes, very often changing keys and giving the melody to different instruments gives an agitated and unstable development. While the orchestra plays the main theme, the piano has an accompaniment role with a march-like theme. This is followed by a piano solo, which leads into a descending chromatic passage and concludes with an eerie French horn solo. The second movement is in nocturne like form and opens with a series of slow chords on the strings. The piano enters, playing a 
simple arpeggiated figure. The main theme is initially introduced by the flute, followed by an extensive clarinet solo. The third movement is in a playful and lively mood and opens with a short orchestral introduction followed by a piano solo leading to the statement of the agitated first theme. Afterwards a lyrical theme is introduced by the oboe and violas with the motif of the first movement's second theme. Near the end, the second theme is played in fortissimo orchestration and the concerto ends with a fast, ecstatic coda. Approximately 35:00 minutes.

12) Sergei Rachmaninoff: Symphony No. 2 in E minor, Op. 27. Has four movements Largo-Allegro moderato (E minor), Allegro molto (A minor), Adagio (A major), and Allegro vivace (E major). The symphony is composed with a dramatic sequence of Russian symphonic tradition. The main motif is an unending and beautiful flow of the melody. Approximately 60:52 minutes

13) Edvard Grieg: Peer Gynt Suite No. 1, Op. 46. The suite opens with a piece called "Morning Mood" built on a static harmonic background that effectively emulates the stillness of the first moments of dawn which is announced by the flutes, and oboes. Harmonic inflections and bright flute trills join to the music at the end of this section. "Aese's Death" one tiny melodic fragment, an absolutely unchanging rhythm followed by "Anitra's Dance" after a single, magical E major chord. Anitra's Dance is a violin melody over a compelling pizzicato background with harmonic changes. The last piece of the suite is "In the Hall of the Mountain King", which is built on just one small, repetitive thematic fragment that grows wilder and wilder like a whirlwind. Approximately 14:18 minutes

14) Edvard Grieg: Piano Concerto in A Minor Op. 16. The concerto is in three movements: Allegro molto moderato (A minor), Adagio (D flat major), Allegro moderato molto e marcato-Quasi presto-Andante maestoso (A minor-F major-A minor-A major). The first movement is in the sonata form. Begins with tympani roll and is followed by dramatic piano flourish. The movement ends with a virtuosic cadenza and a similar flourish as at the beginning. The opening flourish is based around the motif of a falling minor second followed by a falling major third, which is typical for the folk music of Norway. The second movement is lyrical and leads directly to the third movement. The third movement opens with an energetic theme and is followed by a lyric one. The movement concludes with the Andante maestoso in A Major. In the last movement of the concerto, similarities to a Norwegian folk dance and imitations of the Norwegian folk fiddle can be heard. Approximately 28:00 minutes.

\section{Procedure}

This study was conducted at the very beginning of the academic year in order to exclude the possible anxiety and stress of exams and academic achievement. On the first day of the study, the students in both groups filled out a socio-demographic questionnaire, DASS-42, Oxford Happiness Questionnaire and Satisfaction with Life Scale. The previously validated Turkish versions of all scales were used. 69 different numbers with four digits were written separately on pieces of papers and put into a box. Every participant took a piece of paper from this box and wrote the number on the paper at the top of the questionnaire and scales that she/he filled out. The students were told to keep the piece of paper in a safe place and not to lose it otherwise she or he would be excluded from the study. We did not collect identification information. From the $2^{\text {nd }}$ to the $29^{\text {th }}$ day of the study, every day for 30 minutes, the participants listened to music pieces (which are described in detail above) as per their allocated groups. The selected music pieces were played at a comfortable volume from commercial compact disc recordings over a high quality amplifier and loudspeakers. On the last day of the study, the participants were asked if they had experienced a major life event since the beginning of the study. These were accepted as the loss of or newly diagnosed serious illness of a first degree family member (parents, sisters/brothers, grandparents, uncles or aunts) or for the participant being diagnosed with a serious illness. None of the participants reported such an event. The data were again collected using the DASS42, Oxford Happiness Questionnaire and Satisfaction with Life Scale and the participants were asked to write the same number at the top of the printed scales which they had used on the first day of the study. Every student participated in the music listening sessions, filled out the scales properly with their numbers at the top and during the study period nobody experienced a major life event. Therefore the drop-out rate was zero.

\section{Analyses}

Analysis of the collected data was performed using the SPSS package program. Besides descriptive analyses, student t-test, Mann Whitney U Sign Ranks test, Wilcoxon sign test, Kruskall-Wallis variance analysis and linear regression analysis were conducted.

\section{Results}

\section{Results for the Whole Study Group ( $\mathrm{N}=69$ )}

\section{Socio-Demographic Characteristics}

Of the 69 participants, $36(52.2 \%)$ were first year students and $33(47.8 \%)$ were second year students. The students were 46 females $(66.7 \%)$ and 23 males $(33.3 \%)$ with a mean age of $19.2 \pm 1.5$ years (range $17-24$ years). Distribution of the participants according to their parents' educational status is shown in Table 1.

Most of the participants' mothers were housewives (55.1\%) and $4.3 \%$ of the participants' fathers were unemployed. According to the economic status of their families, the participants assessed their economic status as follows: $26.0 \%$ good, $55.1 \%$ moderate, and $18.8 \%$ poor. Most of the participants $(68.1 \%)$ had one sister/brother, $89.9 \%$ of the students mentioned that their parents were alive and $82.6 \%$ said that their parents were still married. Those who were living at home together with their family members were $40.5 \%$, whereas $33.3 \%$ were living in

Table 1.

Educational status of parents

\begin{tabular}{ccccc}
\hline \multirow{2}{*}{ Education } & \multicolumn{2}{c}{ Mother } & \multicolumn{2}{c}{ Father } \\
\cline { 2 - 5 } & $\mathrm{N}$ & $\%$ & $\mathrm{~N}$ & $\%$ \\
\hline Primary (ISCED level 1) & 21 & 30.4 & 12 & 17.4 \\
Secondary (ISCED level 2) & 12 & 17.4 & 4 & 5.8 \\
High School (ISCED level 3) & 16 & 23.2 & 28 & 40.6 \\
University (ISCED level 6) & 20 & 29.0 & 25 & 36.2 \\
\hline
\end{tabular}

Note: ISCED = International Standard Classification of Education 2011. Available at: http://www.uis.unesco.org/Education/Documents/isced-2011-en.pdf. 
dormitories, and $26.1 \%$ were living in a house together with friends. Regarding their residential place before university, the participants answers were as follows: $55.2 \%$ big city, $21.7 \%$ city, $21.7 \%$ small town and $1.4 \%$ village. $89.9 \%$ of the participants were satisfied with their current education.

\section{Depression, Anxiety and Stress Scores}

The mean depression, anxiety and stress scores at the beginning and end of the study are shown in Table 2.

Paired t-tests were performed in order to assess the difference between the first and last day measurements and no statistically significant difference was determined.

Distribution of participants according to their depression, anxiety and stress levels measured on the first and last day of the study is shown in Table 3.

No statistically significant relationships were found in terms of studied socio-demographic characteristics of the participants and their depression, anxiety and stress status.

\section{Happiness and Life Satisfaction Scores}

The mean happiness and life satisfaction scores at the beginning and end of the study are shown in Table 4.

The range of the Oxford Happiness Questionnaire is 29 - 174

Table 2.

Mean depression, anxiety and stress scores on the $1^{\text {st }}$ and last days of the study.

\begin{tabular}{|c|c|c|}
\hline & \multicolumn{2}{|c|}{ Depression } \\
\hline & First & Last \\
\hline Min-Max Values & $0-27$ & $0-35$ \\
\hline \multirow[t]{3}{*}{ Mean $\pm \mathrm{SE}$} & $8.9 \pm .8$ & $9.3 \pm .9$ \\
\hline & \multicolumn{2}{|c|}{ Anxiety } \\
\hline & First & Last \\
\hline Min-Max Values & $0-28$ & $0-31$ \\
\hline \multirow[t]{3}{*}{ Mean $\pm \mathrm{SE}$} & $10.1 \pm .7$ & $10.0 \pm .9$ \\
\hline & \multicolumn{2}{|c|}{ Stress } \\
\hline & First & Last \\
\hline Min-Max Values & $0-35$ & $1-36$ \\
\hline Mean \pm SE & $15.7 \pm .9$ & $16.8 \pm 1.1$ \\
\hline
\end{tabular}

Table 3.

Percent distribution of the participants regarding depression, anxiety and stress levels on the $1^{\text {st }}$ and last days of the study.

\begin{tabular}{ccccccc}
\hline \multirow{2}{*}{ Level } & \multicolumn{2}{c}{ Depression } & \multicolumn{2}{c}{ Anxiety } & \multicolumn{2}{c}{ Stress } \\
\cline { 2 - 7 } & First & Last & First & Last & First & Last \\
\hline Normal & 60.9 & 60.9 & 42.0 & 43.5 & 46.4 & 44.9 \\
Mild & 14.5 & 13.0 & 11.6 & 13.0 & 20.3 & 13.0 \\
Moderate & 17.4 & 14.5 & 21.7 & 20.3 & 24.6 & 24.6 \\
$\begin{array}{c}\text { Severe + Extremely } \\
\text { Severe }\end{array}$ & 7.2 & 11.6 & 24.7 & 23.2 & 8.7 & 17.5 \\
\hline
\end{tabular}

Table 4.

Mean happiness and life satisfaction scores on the $1^{\text {st }}$ and last days of the study.

\begin{tabular}{ccccc}
\hline & \multicolumn{2}{c}{ Oxford Happiness Score } & \multicolumn{2}{c}{ Life Satisfaction Score } \\
\hline & First & Last & First & Last \\
$\begin{array}{c}\text { Min-Max } \\
\text { Values }\end{array}$ & $59-162$ & $71-158$ & $8-35$ & $6-35$ \\
Mean \pm SE & $114.3 \pm 2.4$ & $113.3 \pm 2.1$ & $22.3 \pm .8$ & $21.6 \pm .8$ \\
\hline
\end{tabular}

points. In this study students scored approximately 113 - 114 points indicating a moderate level of happiness. No statistically significant difference was found between the first and last measurements of happiness score and no significant relationships were determined between the happiness score and studied socio-demographic characteristics of the students.

The range of Satisfaction with Life Scale is 5 - 35 points. In this study students scored approximately $21-22$ points indicating a moderate level of life satisfaction. No statistically significant difference was found between the first and last measurements of life satisfaction score. Except for economic status there were no significant relationships between the life satisfaction score and other socio-demographic characteristics of the students. The relationship between economic status and life satisfaction is shown in Table 5.

Students who reported that they had a good or moderate economic status scored higher life satisfaction scores than those in poor economic status in both of the measurements.

\section{The Relationship between DASS-42, Oxford Happiness and} Satisfaction with Life Scores

Linear regression analysis was performed to assess the relationship between DASS-42 and Oxford Happiness Scale as well as between DASS-42 and Satisfaction with Life Scale scores separately for both of the measurements on the first and last days of the study. The results are shown in Tables 6 and 7.

For both of the measurements, the anxiety and stress scores were not significantly correlated to happiness scores. A negative significant correlation was determined between depression and happiness scores.

For both of the measurements, the anxiety and stress scores were not significantly correlated to life satisfaction scores. A negative significant correlation was determined between depression and life satisfaction scores.

\section{The Effect of Different Types of Classical Music on DASS-42, Oxford Happiness and Satisfaction with Life Scores}

Group I students listened to Baroque classical music and Group II students listened to romantic/post romantic classical music pieces. Table 8 shows the mean scores of DASS-42, Oxford Happiness and Satisfaction with Life Scales on the first and last measurements for both groups.

The difference between the first scores of all the scales for Group I and Group II students were assessed by the Mann Whitney U test and were not found to be statistically significant. Similar results were obtained for the last scores. This means that the depression, anxiety, stress, happiness and life satisfaction status of the students in Groups I and II are no different from each other. 
Table 5.

Economic status and Life Satisfaction Scores.

\begin{tabular}{ccc}
\hline \multirow{2}{*}{ Economic Status } & \multicolumn{2}{c}{ Life Satisfaction Scores $($ Mean $\pm \mathrm{SE})$} \\
\cline { 2 - 3 } & First & Last \\
\hline Good & $26.3 \pm 1.4$ & $25.0 \pm 1.7$ \\
Moderate & $21.6 \pm 1.0$ & $21.3 \pm .8$ \\
Poor & $18.7 \pm 1.5$ & $17.8 \pm 1.9$ \\
\hline
\end{tabular}

Note: Kruskall Wallis Variance Analysis: 1) Measurement $\chi^{2}=11.3$, df $=2, p$ $=.004,2$ ) Measurement $\chi^{2}=10.2, \mathrm{df}=2, p=.006$.

Table 6.

Linear Regression of Students' DASS-42 and Oxford Happiness Questionnaire Scores.

\begin{tabular}{cccccc}
\hline & $\mathrm{B}$ & Std Error & Beta & $\mathrm{t}$ & $p$ \\
\hline First day & & & & & \\
Depression & -2.165 & .362 & -.710 & -5.978 & $\mathbf{. 0 0 0}$ \\
Anxiety & .276 & .457 & .084 & .605 & .547 \\
Stress & -.152 & .380 & -.057 & -.401 & .690 \\
& $\mathrm{R}=.697 ; \mathrm{R}^{2}=.486$ & & & \\
Last day & & & & & \\
Depression & -1.309 & .297 & -.606 & -4.407 & .000 \\
Anxiety & -.223 & .336 & -.098 & -.663 & .509 \\
Stress & -.060 & .328 & -.030 & -.184 & .855 \\
& $\mathrm{R}=.700 ; \mathrm{R}^{2}=.490$ & & & \\
\hline
\end{tabular}

Note: Dependent variable: Oxford Happiness Questionnaire Score.

Table 7.

Linear Regression of Students' DASS-42 and Satisfaction with Life Scale Scores.

\begin{tabular}{cccccc}
\hline & $\mathrm{B}$ & Std Error & Beta & $\mathrm{t}$ & $p$ \\
\hline First day & & & & & \\
Depression & -.696 & .130 & -.713 & -5.357 & $\mathbf{. 0 0 0}$ \\
Anxiety & .153 & .164 & .145 & .932 & .355 \\
Stress & .071 & .136 & .084 & .528 & .600 \\
& & $\mathrm{R}=.595 ; \mathrm{R}^{2}=.354$ & & \\
Last day & & & & & \\
Depression & -.465 & .126 & -.598 & -3.684 & .000 \\
Anxiety & .196 & .143 & .239 & 1.370 & .175 \\
Stress & -.080 & .140 & -.111 & -.573 & .568 \\
& & $\mathrm{R}=.538 ; \mathrm{R}^{2}=.289$ & & \\
\hline
\end{tabular}

Note: Dependent variable: Satisfaction with Life Score.

The difference between the first and last scores for all the scales within Group I and Group II were assessed by the Wil- coxon Signed Ranks Test and were not found to be statistically significant. This means that the different types of music had no effect on students' depression, anxiety, stress, happiness and life satisfaction status.

\section{Discussion}

A study of university students in Canada indicated that students with a higher socio-economic status were more satisfied with life (Chow, 2005). Another study showed that financial behaviors and financial satisfaction, along with academic performance and satisfaction, contribute to the life satisfaction of college students (Xiao, Tang, \& Shim, 2009). According to another study of college students, financial status is the single most important factor for satisfaction with life in general (Lackland Sam, 2001). In terms of life satisfaction and economic status the results of the current study are similar to many other studies on this subject. In this study, the life satisfaction score was found to be $22.3 \pm .8$ and $21.6 \pm .8$ for the first and last measurements respectively. This finding is in line with the life satisfaction scores of other studies of Turkish university students (Gundogan, Sallan Gul, Uskun, Demirci, \& Kececi, 2007; Yetim, 2003).

In this study the mean Oxford Happiness scores varied from $114.3 \pm 2.4$ to $113.3 \pm 2.1$ for the first and last measurements respectively. A recent study of 1038 Turkish university students found the mean Oxford happiness score to be $119.92 \pm .61$. It can be said that the group of students in the current study had significantly lower scores in terms of happiness than those of the previous student group (Dogan \& Sapmaz, 2012). This difference may be due to the higher levels of depression among our study group hence the relationship between depression and happiness was found to be statistically significant.

The second part of this study aimed to assess the effects of the type of music listened to (Baroque or romantic/post romantic) on depression, anxiety, stress as well as on happiness and life satisfaction. No significant differences were found between the two groups in terms of the studied parameters of Baroque classical music and romantic/post romantic classical music. Music therapy as an important means of intervention on depression, has been shown to be effective in reducing depressive mood (Erkkila et al., 2011; Smolen, Topp, \& Singer, 2002). The impact of music on arousal and mood has been well-established in previous studies (Sloboda \& Juslin, 2001; Gabrielson, 2001; Husain, Thompson, \& Schellenberg, 2002). Husain, Thompson \& Schellenberg (2002) asked their participants to complete a spatial test after listening to slow, sad-sounding music (Albinoni's Adagio) or to an up-tempo, happy-sounding piece (Mozart sonata K.448, First Movement). Those who listened to Mozart's sonata exhibited higher levels of arousal and more positive moods than their counterparts who listened to Albinoni's Adagio. In the same study the main effect of key was evaluated and the first movement of Mozart's sonata K. 448 which is originally in D Major was converted to D Minor. Participants who heard the piece in the major key had above-average improvements in mood after listening to the music, whereas those who heard the minor key version had belowaverage improvements. In other words mood improved after listening to the piece in a major key, but it declined or remained unchanged in a minor key (Husain, Thompson, \& Schellenberg, 2002). In the current study, different types of classical music which were also in different keys (major or minor) seemed not 
Table 8.

DASS-42, Oxford Happiness and Satisfaction with Life Scale scores of Group I and Group II.

\begin{tabular}{clllc}
\hline & \multicolumn{2}{c}{ Group I: Baroque Music } & \multicolumn{2}{c}{ Group II: Romantic/Post Romantic Music } \\
\hline & First Score & Last Score & First Score & Last Score \\
Depression & $9.43 \pm 1.20$ & $10.23 \pm 1.46$ & $8.26 \pm 1.06$ & $8.32 \pm 1.34$ \\
Anxiety & $10.82 \pm 1.12$ & $11.40 \pm 1.52$ & $9.32 \pm .97$ & $8.59 \pm 1.07$ \\
Stress & $15.57 \pm 1.37$ & $15.71 \pm 1.61$ & $15.8 \pm 1.24$ & $15.53 \pm 1.21$ \\
Oxford Happiness & $113.1 \pm 3.29$ & $111.9 \pm 3.05$ & $115.3 \pm 3.6$ & $114.7 \pm 3.04$ \\
Life Satisfaction & $22.34 \pm 1.07$ & $21.46 \pm 1.11$ & $22.18 \pm 1.2$ & $21.79 \pm 1.09$ \\
\hline
\end{tabular}

to affect mood. This may be due to the familiarity of the music education students with the music as our study group studied music and they listened to and played music in their daily practice.

\section{Conclusion}

The results of our study suggest that music education students are at risk of depression, anxiety and stress. Their life satisfaction levels are similar to other students whereas their happiness levels are lower. Their economic status has an important impact on their life satisfaction but not on their happiness levels. The intervention of listening to different types of classical music for a period of four weeks for 30 minutes per day had no impact on their psychological well-being. Growing awareness of health issues is a fairly recent development among musicians and music teachers in Turkey. A branch of medicine dealing with the performing arts should be established in order to reduce both physical and psychological injuries in performing artists, students and teachers. Institutions should assist students to acquire knowledge from qualified professionals and authoritative medical sources regarding the maintenance of professional health and the prevention of injuries or disorders.

\section{Acknowledgements}

The authors express their thanks to Mrs. Caroline J. Walker for her support in proofreading and editing the English language of this manuscript.

\section{REFERENCES}

Adewuya, A. O., Ola, B. A., Olutayo, O. A., Mapayi, B. M., \& Oginni, O. O. (2006). Depression amongst Nigerian university students. Prevalence and socio-demographic correlates. Social Psychiatry \& Psychiatric Epidemiology, 41, 674-678. http://dx.doi.org/10.1007/s00127-006-0068-9

Aktekin, M., Karaman, T., Senol, Y. Y., Erdem, S., Erengin, H., \& Akaydin, M. (2001). Anxiety depression and stressful life events among medical students: A prospective study in Antalya, Turkey. Medical Education, 35, 12-17. http://dx.doi.org/10.1046/j.1365-2923.2001.00726.x

Antony, M. M., Bieling, P. J., Cox, B. J., Enns, M. W., \& Swinson, R. P. (1998). Psychometric properties of the 42 item and 21 item versions of the depression anxiety stress scales in clinical groups and a community sample. Psychological Assessment, 10, 176-181. http://dx.doi.org/10.1037/1040-3590.10.2.176

Arslan, G., Ayranci, U., Unsal, A., \& Arslantas, D. (2009). Prevalence of depression, its correlates among students, and its effect on health-related quality of life in a Turkish university. Upsala Journal of Medical Sciences, 114, 170-177.

http://dx.doi.org/10.1080/03009730903174339

Bayram, N., \& Bilgel, N. (2008). The prevalence and socio-demographic correlations of depression, anxiety and stress among a group of university students. Social Psychiatry and Psychiatric Epidemiology, 43, 667-672. http://dx.doi.org/10.1007/s00127-008-0345-x

Bilgel, N., \& Bayram, N. (2010). Turkish version of the depression anxiety stress scale (DASS-42): Psychometric properties. Archives of Neuropsychiatry, 47, 118-126.

Bernhard, H. C. (2005). Burnout and the college music education major. Journal of Music Teacher Education, 15, 43-51.

http://dx.doi.org/10.1177/10570837050150010107

Bernhard, H. C. (2010). A Survey of burnout among college music majors. A replication. Music Performance Research, 3, 31-41.

Bostanci, M., Ozdel, O., Oguzhanoglu, N. K., Ozdel, L., Ergin, A., Ergin, N., Atesci, F., \& Karadag, F. (2005). Depressive symptomatology among university students in Denizli, Turkey: Prevalence and socio-demographic correlates. Croatian Medical Journal, 46, 96100 .

Chow, H. P. H. (2005). Life satisfaction among university students in a Canadian prairie city: A multivariate analysis. Social Indicators Research, 70, 139-150. http://dx.doi.org/10.1007/s11205-004-7526-0

Crawford, J. R., \& Henry, J. D. (2003). The depression anxiety stress scales (DASS): Normative data and latent structure in a large non clinical sample. British Journal of Clinical Psychology, 42, 111-131. http://dx.doi.org/10.1348/014466503321903544

Demirbatir, E., Bayram, N., \& Bilgel, N. (2012). Is the healing force of music far away from the undergraduate music education students? International Journal of Academic Research in Business and Social Sciences, 2, 341-354. http://www.hrmars.com/admin/pics/531.pdf

Diener, E., Enmors, R. A., Larsen, R. J., \& Griffin, S. (1985). The satisfaction with life scale. Journal of Personality Assessment, 49, 71-75. http://dx.doi.org/10.1207/s15327752jpa4901 13

Dogan, T., \& Cotok, N. A. (2011). The validity and reliability of the Turkish version of Oxford Happiness Scale Short. Turkish Psychological Counseling and Guiding Journal, 4, 165-172. (in Turkish) http://pdrdergisi.org/edergi/index.php/pdredergi/article/view/176

Dogan, T., \& Sapmaz, F. (2012). Examination of psychometric properties of the Turkish version form of the Oxford Happiness Questionnaire in university students. Düşünen Adam: The Journal of Psychiatry and Neurological Sciences, 25, 297-304. http://dx.doi.org/10.5350/DAJPN2012250401

Erkkila, J., Punkanen, M., Fachner, J., Ala-Ruona, E., Pöntiö, I., Tervaniemi, M., Vanhala, M., \& Gold, C. (2011). Individual music therapy for depression: Randomized controlled trial. The British Journal of Psychiatry, 199, 132-139. http://dx.doi.org/10.1192/bjp.bp.110.085431

Evans, D. (2002). The effectiveness of music as an intervention for hospital patients: A systematic review. Journal of Advanced Nursing, 37, 8-18. http://dx.doi.org/10.1046/j.1365-2648.2002.02052.x

Gabrielsson, J. A. (2001). Emotions in strong experiences with music. In P. N. Juslin, \& J. A. Sloboda (Eds.), Music and emotion: Theory and research (pp. 431-449). New York: Oxford University Press.

Gjerde, P. F. (1993). Depressive symptoms in young adults: A devel- 
opmental perspective on gender differences. In: D. C. Funder, D. R. Parke, C. A. Tomilinson-Keasey, \& K. Widaman (Eds.), Studying lives through time (pp. 255-288). Washington, DC: APA Publications.

Gundogan, D., Sallan Gul, S., Uskun, E., Demirci, S., \& Kececi, D. (2007). Investigation of the predictors of life satisfaction in university students. Klinik Psikiyatri, 10, 14-27. (in Turkish) http://www.klinikpsikiyatri.org/issues/54

Hills, P., \& Argyle, M. (2002). The Oxford Happiness Questionnaire: A compact scale for the measurement of psychological well-being. Personality and Individual Differences, 33, 1073-1082. http://dx.doi.org/10.1016/S0191-8869(01)00213-6

Husain, G., Thompson, W. F., \& Schellenberg, E. G. (2002). Effects of musical tempo and mode on arousal, mood, and spatial abilities. $\mathrm{Mu}$ sic Perception: An Interdisciplinary Journal, 20, 151-171. http://dx.doi.org/10.1525/mp.2002.20.2.151

Karaoglu, N., \& Karaoglu, M. A. (2009). Does coping with music as an art reduce anxiety and depression symptoms? A comparison of conservatoire and other faculty students. TAF Preventive Medicine Bulletin, 8, 465-472. (in Turkish)

http://www.scopemed.org/fulltextpdf.php?mno=641

Koker, S. (1991). Comparison of life satisfaction among normal and problematic adolescents. Yayinlanmamis yuksek lisans tezi. Unpublished Master Thesis, Ankara: Ankara Universitesi Sosyal Bilimler Enstitusu. (in Turkish)

Lackland Sam, D. (2001). Satisfaction with life among international students: An exploratory study. Social Indicators Research, 53, 315-337. http://dx.doi.org/10.1023/A:1007108614571

Lovibond, S. H., \& Lovibond, P. F. (1995a). Manual for the depression anxiety stress scales. Sydney: Psychology Foundation.

Lovibond, S. H., \& Lovibond, P. F. (1995b). The structure of negative emotional states: Comparison of the depression anxiety stress scales (DASS) with the beck depression and anxiety inventories. Behavior Research Therapy, 33, 335-343.

http://dx.doi.org/10.1016/0005-7967(94)00075-U

Nerdrum, P., Rustøen, T., \& Rønnestad, M. H. (2006). Student psychological distress: A psychometric study of 1750 Norwegian 1st-year undergraduate students. Scandinavian Journal of Educational Research, 50, 95-109. http://dx.doi.org/10.1080/00313830500372075

Orzel, H. J.(2010). Undergraduate music student stress and burnout. Master's Theses, Paper 3887.

http://scholarworks.sjsu.edu/etd_theses/3887

Ovuga, E., Boardman, J., \& Wasserman, D. (2006). Undergraduate student mental health at Makerere University Uganda. World Psychiatry, 5, 51-52.

Ozdemir, H., \& Rezaki, M. (2007). General health questionnaire-12 for the detection of depression. Turk Psikiyatri Dergisi, 18, 1-8.

Poch, F. V., Villar, E., Caparros, B., Juan, J., Cornella, M., \& Perez, I. (2004). Feelings of hopelessness in a Spanish university population. Descriptive analysis and its relationship to adapting to university. depressive symptomatology and suicidal ideation. Social Psychiatry \& Psychiatric Epidemiology, 39, 326-334. http://dx.doi.org/10.1007/s00127-004-0756-2

Rao, D., Nainis, N., Williams, L., Langner, D., Eisin, A., \& Paice, J. (2009). Art therapy for relief of symptoms associated with HIV/ AIDS. AIDS Care, 21, 64-69.

http://dx.doi.org/10.1080/09540120802068795
Royal College of Psychiatrists (2003). The mental health of students in higher education. Council Report CR112, London.

http://www.healthyuniversities.ac.uk/uploads/files/rcp_mental_health report2003.pdf

Seker, H., \& Gencdogan, B. (2006). Developing measurement instruments in psychology and education. Ankara: Nobel Yayin Dagitim. (in Turkish)

Sloboda, J. A., \& Juslin, P. N. (2001). Psychological perspectives on music and emotion. In P. N. Juslin, \& J. A. Sloboda (Eds.), Music and emotion: Theory and research (pp. 71-104). New York: Oxford University Press.

Smolen, D., Topp, R., \& Singer, L. (2002).The effect of self selected music during colonoscopy on anxiety, heart rate, and blood pressure. Applied Nursing Research, 15, 126-136. http://dx.doi.org/10.1053/apnr.2002.34140

Spahn, C., Strukely, S., \& Lehmann, A. (2004). Health conditions. attitudes toward study and attitudes toward health at the beginning of university study: Music students in comparison with other student populations. Medical Problems of Performing Arts, 19, 26-33.

Stanley, N., \& Manthorpe, J. (2001). Responding to students' mental health needs: Impermeable systems and diverse users. Journal of Mental Health, 10, 41-52. http://dx.doi.org/10.1080/09638230020023606

Sternbach, D. J. (2008).Stress in the lives of music students. Music Educators Journal, 94, 42-48.

http://dx.doi.org/10.1177/002743210809400309

Stewart-Brown, S., Evans, J., Patterson, J., Petersen, S., Doll, H., Balding, J., \& Regis, D. (2000). The health of students in institutes of higher education: An important and neglected public health problem? Journal of Public Health Medicine, 22, 492-499.

http://dx.doi.org/10.1093/pubmed/22.4.492

Thompson, W. F., Schellenberg, E. G., \& Husain, G. (2001). Arousal, mood, and the Mozart effect. Psychological Science, 12, 248-251. http://dx.doi.org/10.1111/1467-9280.00345

Uncu, Y., Bayram, N., \& Bilgel, N. (2007). Job related affective wellbeing among primary health care physicians. European Journal of Public Health, 17, 514-519. http://dx.doi.org/10.1093/eurpub/ckl264

Voelker, R. (2003). Mounting student depression taxing campus mental health services. Journal of American Medical Association, 289, 2055-2056. http://dx.doi.org/10.1001/jama.289.16.2055

Wang, J., Wang, H., \& Zhang, D. (2011). Impact of group music therapy on the depression mood of college students. Health, 3, 151-155. http://dx.doi.org/10.4236/health.2011.33028

Wong, J. G. W. S., Cheung, E. P. T., Chan, K. K. C., Ma, K. K. M., \& Tang, S. W. (2006). Web-based survey of depression, anxiety and stress in first-year tertiary education students in Hong Kong. Australian New Zealand Journal of Psychiatry, 40, 777-782. http://dx.doi.org/10.1080/j.1440-1614.2006.01883.x

Xiao, J. J., Tang, C., \& Shim, S. (2009). Acting for happiness: Financial behavior and life satisfaction of college students. Social Indicators Research, 92, 53-68. http://dx.doi.org/10.1007/s11205-008-9288-6

Yetim, U. (2003). The impacts of individualism/collectivism, selfesteem, and feeling of mastery on life satisfaction among the Turkish university students and academicians. Social Indicators Research, 61, 297-317. http://dx.doi.org/10.1023/A:1021911504113 